\title{
GÊNERO E TERRITÓRIO: ETNOGRAFIA DA CASA COMO ESPAÇO DE PRODUÇÃO DO CORPO E DO SOCIUS
}

\author{
AUTOR: CÁTIA SANTOS OLIVEIRA \\ CO-AUTOR/ORIENTADOR: ANA CARNEIRO CERQUEIRA
}

Resumo: Este projeto propõe a investigação etnográfica das problemáticas de gênero experimentadas em diversos processos de territorialização no Extremo Sul da Bahia. Entendendo as noções de gênero e território como formas específicas de diferenciação social e cultural, perguntamos como as relações de gênero produzem e são produzidas pelo território. Ou seja, buscamos observar o que acontece com o conhecimento sobre as lutas travadas coletivamente em defesa do território ao reconhecermos que seus modos de existência específicos são informados, sobretudo, por relações de gênero e de parentesco. Neste sentido, especial atenção deve ser dada às narrativas femininas sobre o corpo (definindo lógicas, classificações e elaborações ligadas à reprodução e criação de pessoas), de modo a explorar, à luz da linguística de corpus, um viés analítico que se mostrou promissor durante o primeiro ano de execução da pesquisa. Dando continuidade ao que já realizamos, as territorialidades sob análise encontram-se em diversas localidades do município de Porto Seguro e arredores, abrangendo quilombolas, indígenas e agricultores familiares, bem como espaços de circulação traçados por esses povos fora de seus locais de origem e moradia.

Palavras-chave: Ancestralidade, rituais de cura, ebó, religiões afro-brasileiras. 